А. Д. Горбань

\title{
СТАНОВЛЕНИЕ СТИЛИСТИЧЕСКИХ КАНОНОВ В АНГЛИЙСКОЙ ПРОЗЕ ВТОРОЙ ПОЛОВИНЫ ХVІІ ВЕКА
}

Горбань О. Д. Становлення стилістичних канонів в англійській прозі другої половини XVII століття.

У статті розглядаються фактори, що вплинули на формування стилістичних канонів в англійській прозі другої половини XVII сторіччя. Цей період характеризується становленням норми національної англійської літературної мови, коли відбувалося філософське, ліричне, емоційне, інтелектуальне осмислення життєвих змін і розпочалася справжня боротьба в літературі за новий стиль, покликаний відобразити динаміку внутрішнього життя людини.

Виявлено нові стилістичні впливи й ознаки нового стилю у зв'язку 3 провідним літературним напрямом епохи - класицизмом, акцентовано на властивій цьому стилю раціонально-логічній спрямованості. Досліджено есе другої половини XVII сторіччя як проміжний жанр, що виник на перетині літератури, публіцистики й філософії.

Ключові слова: тексти-роздуми, композиція, логіко-структурні особливості, типологія, есе.

๑ А. Д. Горбань, 2016. 
Горбань А. Д. Становление стилистических канонов в английской прозе второй половины XVII века.

В статье рассматриваются факторы, повлиявшие на формирование стилистических канонов в английской прозе второй половины XVII века. Данный период характеризуется становлением нормы национального английского литературного язика, когда происходило философское, лирическое, эмоциональное, интелектуальное осмысление жизненных перемен и началась настоящая битва в литературе за новый стиль, призванный отразить динамику внутренней жизни человека. Исследуются новые стилистические влияния и приметы нового стиля в связи с ведущим литературным направленим епохи - классицизмом, обращается внимание на свойственную этому стилю рационально-логическую направленность. Исследуются эссе второй половины XVII века как промежуточный жанр, возникающий на стыке литературы, публицистики и философии.

Ключевые слова: тексты-рассуждения, композиция, логико-структурные особенности, типологія, эссе.

Gorban O. D. The formation of stylistic canons in English prose of the second half of the seventeenth century.

The article discusses the factors that influenced the formation of stylistic canons in English prose of the second half of the seventeenth century. This period is characterized by the formation of English literature national language norms, when philosophical, lyrical, emotional, intellectual understanding of life changes took place and the battle in the literature over the new style, designed to reflect the dynamics of the inner life of man has begun. Being investigated the stylistic influence and signs of the new style in connection with principal literary direction of epoch - classicism. Attention is drawn to rational-logical direction of this style. The essays of the second half of the XVII century being examined, as an intermediate genre that occurs at the intersection of literature, journalism and philosophy.

Special attention is paid to small epic forms (essays, meditations, diaries), specific language which is dictated by the General structural peculiarities of this prose, strictly rational-logically and rhetorically organized. A significant part of the prose, the period under investigation, represented the argumentative - texts focused on traditional forms of rhetorical prose of antiquity.

The formation of a new stylistic canons in English prose of the XVII century, orienting the tastes on logical and stylistic clarity, is inextricably linked with the appeal to classical models. Ancient rhetoric had a huge impact on the formation of the style of English prose. Particularly important is one of the components of ancient rhetoric - style. The struggle for a new style, simple and natural especially widely and pointedly turned around in this period in ecclesiastical literature. Publishing of huge numbers of sermons implied the existence of readers. They were valued not only for instruction but also as a model of rhetoric and oratory. In literature flood plain words, verbal structures and conversational intonations. Among the significant reasons that influenced the development of prose of the period, marked - impact of journalism, the revival of political struggle, expressed in the sharp political debate, rationalist approach to the language generated by a philosophy of rationalism. The evolution of prose style in the second half of the XVII century was subordinated to the chief - the creation of the truthfulness and ease of communicating ideas. 
The element of reasoning covered the whole of the prose, the sermons, treatises, essays. The general stylistic requirements of English prose have been formulated.

Key words: reasoning texts, composition, logic-structural peculiarities, typology, essay.

Вторая половина XVII века - период бурного развития английской прозы, о чём свидетельствуют не только произведения таких значительных прозаиков как Т. Браун, Д. Тейлор, А. Каули, В. Темпль, Т. Трахерн, Д. Галифакс, Д. Драйден, но и острая полемика по проблемам языка и стиля литературы, в которой принимали участие писатели и критики Б. Барней (1643-1715), Д. Мильтон (1608-1674).

В XVII веке английская проза набирала размах и силу. Причины такого бурного и яркого взлёта прозы специалисты трактуют поразному. Так В. Ярцева выделяет общеязыковую ситуацию, которая характеризуется в этот период становлением нормы национального литературного языка [2, с. 155], что, несомненно, было весьма значительным для общей тенденции развития литературы. Однако, имелись и другие экстралингвистические причины. Проза XVII века отразила философское, лирическое, эмоциональное, интеллектуальное осмысление жизненных перемен, когда в сложной политической обстановке в стране началась настоящая битва в литературе за новый стиль, призванный отразить динамику внутренней жизни человека $[1$, c. 29]. Отсюда такой мощный поток текстов с ярко выраженной структурой рассуждения, формирование жанров, в определениях которых была заложена эта речемыслительная особенность: анатомии, характеры, медитации, философско-религиозные эссе.

В середине XVII века, когда напряжённая социальная и идеологическая борьба, происходящая в стране, достигла своего апогея в буржуазной революции, когда специальным постановлением Долгого парламента от 1642 года в Англии были запрещены театральные представления, а пуританство воздвигло непреодолимые барьеры перед драмой, наиболее распространённой и массовой формой литературы в период реставрации становится полемическая, 
философская, интимно-психологическая проза.

Английский исследователь Борис Форд, изучающий развитие английской литературы, указывает на тесную связь, существующую между развитием литературы и развитием общества:

"When men desired stability in politics and society, they advocated stability in language. Since correctness and elegance became the ideals in literature, words and their usage had to be submitted in life and thought must be reflected clear gracefully structure and cadence of Sentences" [6, c. 125].

Становление новых стилистических канонов в английской прозе XVII века, ориентирующих вкусы на логическую ясность, доходчивость и стилистическую прозрачность, было неразрывно связано с обращением к классическим образцам. Античная риторика оказала огромное влияние на формирование стиля английской прозы. Особую популярность приобретает одна из составных частей античной риторики - стилистика.

Родившись, как теория красноречия, риторика постепенно становится нормативной теорией прозы вообще. Известный ещё в древности спор между сторонниками стиля Сенеки и стиля Цицерона был подхвачен английскими прозаиками второй половины XVII века. Об этом пишет видный специалист в области английского прозаического стиля Роберт Адольф:

"Literary history in the Renaissance is a duplication of the struggle between the genera of antiquity" [3, с. 14].

В Англии получила распространение именно «стилистическая» часть риторики. Обострённое внимание к выбору слов, их стилистической окрашенности, отработка распространённого периода, создающего перспективу в развитии мысли пишущего характерны для стиля таких английских прозаиков, как Т. Браун, Р. Бэртон (1576-1640), Т. Трахерн.

Р. Адольф рассматривает новые стилистические веяния и приметы "new style" в связи с ведущим литературным направлением 
эпохи - классицизмом, обращая внимание на свойственную этому литературному стилю рационально логическую оформленность [3, c. 6-7].

В классических чертах нового стиля учёный видит как влияние античности, так и новые веяния времени - открытия в области философии, науки. Поэтому он и призывает изучать несомненно существующие связи между анти-цицеронианским движением прозаиков и развитием научной мысли. исследователем отмечено очень важное явление - изменение в природе самой прозы - движение от занятости самовыражением (в начале века мы можем увидеть это в прозе Донна, Бэртона, Брауна) к художественному воспроизведению и познанию внешнего мира.

Именно это наблюдение даёт исследователю возможность рассматривать анти-цицеронистские тенденции в литературе не как проявление сенеканских ориентаций, а как новое стилистическое явление, отражающее новый тип научного рационального мышления века:

"Since the style of all prose of the Restoration period is commonly said to reflect "scientific" norms, and since almost all prose of the entire century has been claimed for "anti-ciceronianism" and "science" would necessitate a general history of seventeenth-century prose" [3, c. 8].

Таким образом, известная антитеза Цицерон (старый стиль) Сенека (новый стиль), усложняется выделением нового стилистического явления, ориентированного на простоту и понятность.

Усвоение стилистических открытий начала XVII века шло через диалектическое «снятие», а не простое отрицание сложности и защиту простоты как простомыслия. Поэтому и лёгкость восприятия прозы этого периода едва ли можно признать исчёрпывающей научной характеристикой явления. Осмысление закономерностей возникновения, становления и развития так называемого «нового стиля», ставшего основой самых распространённых во второй половине XVII века текстов-рассуждений - проблема, до сих пор не 
изученная современной наукой. Среди исследователей нет единогласия ни в отношении определения "stylistic standard", ни в отношении его хронологии.

Так, один из самых важных теоретиков английского прозаического стиля этого периода М. Кролл, влияние работ которого на современные концепции развития английской прозы являются решающим, ведёт отсчёт зарождения нового стиля с 1600 года, когда появились такие писатели, как Бэкон (1561-1626) и Бэртон и началось движение, аналогичное стилистической борьбе античности. Кролл считает антицицеронизм доминирующим стилем в английской литературе XVII века и выделяет 3 направления в его развитии: “the curt" связывает со стилем Линия, "loose" - с Монтенем, "obscure" - с Бэконом. При этом, по его мнению, краткий (curt) и освобождённый (loose) стили были сенеканскими по своему характеру, а неясный (obscure) напоминает стиль Тацита.

Кролл полагает, что: “... a prose style that should adequately express this age must contrive therefore, to mingle elements that in any other period would appear oddly contrasted. It must be at once ingenious and lofty, intense yet also profound, acute, realistic, revealing, but at the same time somewhat grave and mysterious" [5, c. 194].

И действительно, если мы обратимся к творчеству самого известного писателя этого периода - Дж. Мильтону (1608-1674), то обнаружим, что он не был ни «цицеронианцем»ни «сенеканцем». Он, как позже и Кларендон, осудил свойственные этому стилю «изысканные» (smart) повороты:

"We represent less the new, direct manner in English prose than the grand finale of the old, mannered style" [8, c. 15].

Кролл придерживался мнения, что именно Бэкон натурализовал «смешанный» стиль в Англии, имитируя Тацита. Плодотворная тенденция рассмотрения появившегося в XVII веке нового «стилистического стандарта» в единстве разных стилистических тенденций, тем не менее, не раскрывает стилистической природы 
этого явления, а импрессионистски-оценочные определения "curt", "loose", “obscure" относятся в основном к описанию синтаксической организации этой прозы, выделяя лишь отдельные и не самые характерные черты нового стиля.

В полемику с Кроллом вступает видный американский стилист P. Джонз, который годом главного «стилистического сдвига» (stylistic shift) называет не начало века, а 1660 год и к тому же генетически не связывает его появление с ориентацией на классику [3, с. 7]. Возникновение нового, а в его характеристике прежде всего «простого стиля» (plain style) - стиля мысли, объясняется исключительно влиянием новых тенденций в науке и философии.

Наиболее отчётливо эти новые тенденции были сформированы Т. Спратом (1635-1713) в «Истории Королевского общества» в которой провозглашается новый стилистический канон: «сдержанный, открытый, естественный стиль» (close, naked, natural style) [7, с. 79].

Верно подмеченная рационально-логическая направленность стилистической тенденции и её обусловленность расцветом «логизированной» литературы, к сожалению, не анализируется учёными. Знаменательно, что почти все зарубежные последователи, занимающиеся проблемой стилистики английской прозы XVII века, разделились на две группы. Одна - придерживается точки зрения Кролла, другая - точки зрения Джонза. Однако понятно, что нельзя сводить всю природу стилистических изменений в прозе этого периода только к двум, несомненно, влияющим на её развитие факторам. Среди иных существенных причин в исследованиях последних лет отмечаются и другие: влияние журналистики, оживление политической борьбы, выразившееся в острых политических дискуссиях, рационалистический подход к языку, порождённый философией рационализма.

Особую роль в становлении стилистических канонов прозы второй половины XVII века играло созданное в 1662 году «Королевское общество». С целью улучшения языка нации в ( А. Д. Горбань, 2016. 
1664 году им был создан специальный комитет, в который вошли такие видные деятели и писатели, как Драйден, Эвелин, Уоллер.

В 1664-1665 годах «Королевское общество» выработало специальную лингвистическую программу, основным требованием которой был простой, непринуждённый стиль и даже призыв возвратиться к "primitive purity and shortness, when men delivered so many things, almost in an equal number of words" [4, c. 39].

Это последнее было крайней, искусственной мерой, необходимой для обретения списателями утраченной способности выражать свои мысли без заранее готових риторических схем.

Ещё одним фактором, повлиявшим на «упрощение» стиля прозы второй половины XVII века, английский исследователь К. Бэртон считает пребывание многих писателей в иммиграции во Франции.

"French was by nature a more Lucid language, and a demand for something of this perspicuity in English was made by the exiles on their return" [4, c. 38].

Борьба за новый стиль, простой и естественный, особенно широко и остро развернулась в этот период в проповеднической литературе. Печаталось огромное количество проповедей, что подразумевало наличие их массового читателя. Они ценились не только за наставления, но и как образец риторики и ораторского искусства. В литературу хлынул поток простых слов, речевых конструкций и разговорных интонаций. Несомненно, что просветительская идеология, которая в Англии стала складываться в конце XVII века, к началу XVIII века во многом определила пути развития стиля английской прозы по пути обретения большей естественности и точности выражения мысли, затронув лексику и синтаксис.

Эволюция стиля прозы второй половины XVII века была подчинена главному - созданию правдивости и непринуждённости передачи мыслей. Стихия рассуждения охватила всю прозу: проповедь, трактат, эссе и даже жанр «характера». В последней четверти XVII века были сформулированы общие стилистические 
требования к английской прозе. Однако, плодотворно начатое исследователями изучение истоков становления современного прозаического стиля, анализ социально-исторических условий его появления и становления в прозе XVII века обнаруживает лишь сложную картину изучаемого явления, которое так и осталось не осмысленным во всей своей целостности, распавшись в противоречивых концепциях учёных на взаимоисключаемые черты. Концепция прозы, как “elegant” и “correct”, которая сложилась в конце XVII века, в результате острой борьбы между сторонниками стилистических крайностей «простоты» и «изощрённости», приводит современных исследователей к убеждению, что в английской прозе складывается канон так называемого “middle style", провозглашённый ещё в античности. Однако и концепция "middle style" лишь условная характеристика основного движения в стилистической организации прозы, которая под индивидуальным пером талантливых писателей выходит за пределы очерченных учёными границ, ставя новые проблемы перед исследователями. Протест против попыток формализовать прозу звучит с особой остротой в заявлении Р. Адольфа: "The best style for prose is not style at all” [3, с. 76].

Существенной чертой прозы этого периода является противоречивость стилевых процессов. С одной стороны, заметно стремление прозаиков стать ближе к предмету, реальности, растворить свой голос в голосах эпохи, а с другой - создать личный стиль.

Требование простоты включало в себя не упрощение формы, не отказ от содержательной глубины и освоения сложности, внутренней противоречивости жизни и человека, а прежде всего новый характер мысли и чувства, синхронные со словом.

Специфика языка и стиля английской прозы второй половины XVII века, наиболее ярко проявляется в малых эпических формах (эссе, медитациях, мемуарах, дневниках), продиктована общей структурной чертой этой прозы, строго рационально-логически и риторически организованной. Значительная часть прозаических 
произведений рассматриваемого периода представляла собой тексты аргументированные рассуждения, ориентированные на традиционные формы риторической прозы античности.

При всей заявленной авторами свободе выражения мыслей эти тексты-рассуждения риторичны. Риторика, как известно, не только искусство убедительной речи, но и искусство организации речи. Риторическая теория прозы оказала мощное влияние на композиционное оформление текстов-рассуждений, прямо связанных с законами красноречия. Проза этого периода насквозь риторична. Возрождение риторики в XVII веке определило и особый характер порождения текстов, в которой обязательной организации подвергаются лексико-семантический и синтаксический уровни. Элемент сознательности и правильности здесь очевиден, поэтому структура предстаёт обнажено. Рассуждение здесь не контаминировано с другими композиционно-речевыми формами, а представляет целое речевое произведение.

Рассматривая эссе второй половины XVII века как промежуточный жанр, возникающий на стыке литературы и публицистики, литературы и философии, необходимо упомянуть о существовании двух разновидностей эссе - formal и informal. Философы и учёные того времени развивали идею опыта как научного эксперимента и обосновывали возможности перехода от него к обобщающим суждениям. Это был тип formal эссе. Наряду с ним в XVII веке проходил процесс формирования informal эссе с «неупорядоченными, неслаженными, выступающими со всех сторон ассоциациями, дополнительными мыслями» [1, с. 81]. Для informal эссе характерны взволнованная непосредственность и риторическая приподнятость, нагромождение сравнений, метафор, градаций. Это естественно для жанра, получившего развитие в период готовящихся революционных изменений, а во времена Английской буржуазной революции ставшего сферой самых напряжённых идейно-художественных изысканий. В эссе важнее всего индивидуальная точка зрения автора, эмоциональная атмосфера, 
вызванная описываемым явлением. В эссе субъект интереснее, чем объект, особенности восприятия существеннее того, что воспринимается.

Рассуждение являлось не одним из привходящих элементов композиционно-речевой структуры цельнооформленных текстов разных жанров (эссе, медитаций, проповедей), а было основой этих текстов в английской прозе рассматриваемого периода.

\section{Литература}

1. Берёзкина В. И. Формирование и пути развития жанра эссе в английской литературе XVII века / В. И. Берёзкина. - Днепропетровск : ДГУ, 1984. - 116 с.

2. Ярцева В.Н. Развитие национального литературного английского языка / В. Н. Арутюнова - М. : Наука, 1969. - 284 с.

3. Adolph R. The rise of modern prose style / R. Adolph. - L. : M.I.T. Press, 1968. - 372 p.

4. Burton K. M. P. Restoration Literature / K. M. P. Burton. - L. : Hutchinson university library, 1956. $-240 \mathrm{p}$.

5. Croll M. W. Style, Rhetoric and Rhythm, Essays / M. W. Croll. - Princeton : Sel. And ed. By I. M Patrik, 1966. - 194 p.

6. Ford B. From Dryden to Johnson / B. Ford. - L. : Penguin Books, 1957. - 510 p.

7. Sprat T. the History of Royal Society Prose works / T. Sprat. - L., 1987. - Vol. 3. - 79 p.

8. Wedgwood C. V. $17^{\text {th }}$ century English Literature / C. V. Wedgwood - L. : N.-Y.; Toronto : Oxford Univ. Press, 1950. - 15 p.

Стаття надійшла до редакиії 12.09.2016 p. 